\title{
THE EFFECT OF DISCIPLINE AND TRAINING TOWARD EMPLOYEE PERFORMANCE
}

\author{
Melda Wiguna \\ Universitas Pamulang, Indonesia \\ dosen02513@unpam.ac.id
}

\begin{abstract}
Organizational resources that have an important role in achieving its goals is human resources. Because of the importance of the role of humans in both short and long term competition on the business agenda, a company must have more value compared to other companies. PT. Mediatama Sejahtera is a company engaged in comprehensive services consisting of printing services (transactional printing service), electronic report making services (E-statement service), printing services (publishing printing service), document scanning services (document imaging service/scanner), Courier service, as well as customized business process management services, business process management services. This study aims to determine the effect of discipline and training on employee performance at PT. Mediatama Sejahtera in Jakarta. The method used was explanatory research with a sample of 86 respondents. The analysis technique uses statistical analysis with regression testing, correlation, determination, and hypothesis testing. The results of this study have a significant effect on discipline employee performance by $46.3 \%$, the hypothesis test obtained significance $0,000<0.05$. The training had a significant effect on employee performance by $35.9 \%$, the hypothesis test obtained a significance of $0,000<0.05$. Discipline and training simultaneously have a significant effect on employee performance. hypothesis-testing obtained significance of $0,000<0.05$.
\end{abstract}

Keywords: Discipline, Training, Employee Performance

INTRODUCTION
One of the organizational
resources that has an important role in achieving its goals is human resources. Because of the importance of the role of humans in both short and long term competition on the business agenda, a company must have more value compared to other companies.

PT. Mediatama Sejahtera is a company engaged in comprehensive services consisting of printing services (transactional printing service), electronic report making services (Estatement service), printing services (publishing printing service), document scanning services (document imaging service/scanner), Courier service, as well as customized business process management services, business process management services.

One factor that is very influential in human resources is the discipline factor. Work discipline can be seen as something of great benefit, both for the interests of the company and for employees, for the company the existence of work discipline will guarantee the maintenance of order and the smooth implementation of tasks so that optimal results are obtained. According to Hasibuan (2016), states that "Discipline is awareness of one's willingness to obey all company regulations and applicable norms". If all training is disciplined, then an employee will participate in the discipline, but if company training is not disciplined, then an employee will also be undisciplined. For this reason, it is very difficult for undisciplined training but wants to apply employee discipline.

Another factor that also greatly affects the achievement of performance is training. Development becomes the most important thing in human resource management both for professionals and managers. Training for employees is very important since it is known that people's knowledge gained from formal education is not enough or is not suitable for the 
company. According to Mangkunegara (2016) stated that Training (training) is a short-term educational process that uses systematic and organized procedures, non-managerial employees learn technical knowledge and skills in limited objectives. More and more employees are allowed to attend training can improve company performance. But in reality, this matter is not getting priority by the company management as evidenced by the data collected showing fluctuating conditions.

As a company that focuses on services, training activities are an important point that must be used as a benchmark in the success of a company considering that in this sector a wide range of technological developments and understanding capabilities increasingly require workers to carry out the targets and allocations set by the company. Improved performance is desirable both from the company and from the employee. The company wants good employee performance for the sake of increasing work results and company profits. On the other hand, employees have an interest in selfdevelopment and job promotion. performance is the result produced by a particular job function or activities on a particular job for a certain period. The work is the result of the ability, expertise, and desire achieved.

In general, it can be said that good employee performance aims to improve performance, therefore improvements to the work system are carried out by every component in the company. For this purpose, a good performance management system will be needed, and discipline is an attitude that must be instilled in all employees to improve employee performance.

The success of the company in managing and empowering human resources which are the company's assets can increase the company's income so that the company can survive amid the onslaught of competition with other similar companies, the key to the company's success, in this case, is inseparable from human factors as a variable that has a very large influence and determines whether or not the company is progressing.

In practice, most companies want high performance but do not try to improve the work discipline of human resources, this becomes difficult in realizing the performance to be achieved for that needs to be further investigated whether the employee work discipline in work.

Based on the description in the background above, the writer is interested in taking the title: "The Effect of Work Discipline and Training on Employee Performance at PT. Mediatama Sejahtera in Jakarta.

Formulation of the problem: (1) Is there a partial effect between discipline on employee performance at PT. Mediatama Sejahtera in Jakarta; (2) Is there a partial effect between training on employee performance at PT. Mediatama Sejahtera in Jakarta; (3) Is there a simultaneous influence between discipline and training on employee performance at PT. Mediatama Sejahtera in Jakarta.

Research purposes: (1) To determine the partial effect between discipline on employee performance at PT. Mediatama Sejahtera in Jakarta; (2) To find out the partial effect between training on employee performance at PT. Mediatama Sejahtera in Jakarta; (3) To find out the simultaneous influence between discipline and training on employee performance at PT. Mediatama Sejahtera in Jakarta. According to Sutrisno (2016) defines Discipline is a person's behavior by regulations, existing work procedures or attitudes and behavior and actions following the regulations of the organization both written and unwritten. In this study indicators used include: obeying the rules of obedience to organizational rules, obeying the rules of behavior at work, obeying other regulations. 
Training is often seen as the most common activity and leaders support training because, through training, workers will become more skilled and therefore more productive even if the benefits must be taken into account with the time taken while workers are being trained.

Training according to Rivai (2014) is a process of systematically changing employee behavior to achieve organizational goals. Training is concerned with the expertise and ability of employees to carry out current work. The training has a current orientation and helps employees to achieve certain skills and abilities to succeed in carrying out their work

According to Mangkunegara (2016) the notion of performance is the work of quality and quantity achieved by an employee in carrying out their duties following the responsibilities given to him.

\section{METHODS}

The population in this study amounted to 86 respondents PT. Mediatama Sejahtera in Jakarta. The sampling technique in this study is saturated sampling, where all members of the population are sampled. Thus the sample in this study amounted to 86 respondents. The type of research used is associative, where the aim is to find out the relationship between variables. In analyzing the data used the instrument test, classical assumption test, regression, coefficient of determination, and hypothesis testing.

\section{RESULTS AND DISCUSSION Descriptive Analysis}

This test used to determine the minimum and maximum scores, mean scores, and standard deviations of each variable. The results are as follows:

Table 1. Results of Descriptive Statistics Analysis

\begin{tabular}{llllll}
\hline & $\mathrm{N}$ & Minimum & Maximum & Mean & Std. Deviation \\
\hline Discipline (X1) & 67 & 31 & 48 & 38.09 & 4.252 \\
Training (X2) & 67 & 30 & 48 & 38.18 & 3.833 \\
Employee Performance (Y) & 67 & 33 & 47 & 39.25 & 3.706 \\
Valid N (listwise) & 67 & & & & \\
\hline
\end{tabular}

Source: processed data (2020)

Discipline obtained a minimum variance of 31 and a maximum variance of 48 with a mean score of 3.81 with a standard deviation of 4.252. Training obtained a minimum variance of 30 and a maximum variance of 48 with a mean score of 3.82 with a standard deviation of 3.833. Employee performance obtained a minimum variance of 33 and a maximum variance of 47 with a mean score of 3.92 with a standard deviation of 3.706 .

\section{Verification Analysis}

This analysis is intended to determine the effect of independent variables on the dependent variable. The test results are as follows:

\section{Multiple Linear Regression Analysis}

This regression test is intended to determine changes in the dependent variable if the independent variable changes. The test results are as follows: 
Table 2. Results of Multiple Linear Regression Testing

\begin{tabular}{|c|c|c|c|c|c|}
\hline \multirow{3}{*}{ Model } & \multicolumn{3}{|c|}{ Coefficients $^{a}$} & \multirow{3}{*}{$\mathrm{t}$} & \multirow{3}{*}{ Sig. } \\
\hline & \multicolumn{2}{|c|}{$\begin{array}{l}\text { Unstandardized } \\
\text { Coefficients }\end{array}$} & $\begin{array}{l}\text { Standardized } \\
\text { Coefficients }\end{array}$ & & \\
\hline & B & Std. Error & Beta & & \\
\hline (Constant) & 10.345 & 3.422 & & 3.024 & .004 \\
\hline Discipline (X1) & .439 & .087 & .504 & 5.024 & .000 \\
\hline Training (X2) & 319 & .097 & .330 & 3.292 & .002 \\
\hline
\end{tabular}

a. Dependent Variable: Employee Performance $(\mathrm{Y})$

Source: processed data (2020)

Based on the test results in the above table, the regression equation $\mathrm{Y}=$ $10.345+0.439 \times 1+0.319 \times 2$ is obtained. From the equation explained as follows:

A constant of 10,345 means that if there is no discipline and training, then there is an employee performance value of 10,345 points. The discipline regression coefficient of 0.439 , this number is positive, meaning that each discipline has an increase of 0.439 , the employee's performance will also increase by 0.439 points. Training regression coefficient of 0.319 , this number is positive, meaning that every time there is an increase in training of 0.319 , employee performance will also increase by 0.319 points.

\section{Correlation Coefficient Analysis}

Correlation coefficient analysis is intended to determine the degree of relationship strength of the independent variables on the dependent variable either partially or simultaneously. The test results are as follows:

Table 3. Results of Discipline Correlation Coefficient Tests on Employee Performance

\begin{tabular}{|c|c|c|c|}
\hline \multicolumn{4}{|c|}{ Correlations $^{\text {b }}$} \\
\hline Discipline (X1) & $\begin{array}{l}\text { Pearson Correlation } \\
\text { Sig. (2-tailed) }\end{array}$ & 1 & $\begin{array}{l}.680^{* *} \\
.000\end{array}$ \\
\hline $\begin{array}{l}\text { Employee } \\
\text { Performance }(\mathrm{Y}) \\
\text { **. Correlation is } \\
\text { b. Listwise } \mathrm{N}=67\end{array}$ & $\begin{array}{l}\text { Pearson Correlation } \\
\text { Sig. (2-tailed) } \\
\text { ficant at the } 0.01 \text { leve }\end{array}$ & $\begin{array}{l}.680^{\star *} \\
.000 \\
\text {-tailed). }\end{array}$ & 1 \\
\hline
\end{tabular}

Source: processed data (2020)

Based on the test results obtained a correlation value of 0.680 means that discipline has a strong relationship with employee performance.

Table 4. Test Results for Training Correlation Coefficient on Employee Performance

\begin{tabular}{|c|c|c|c|}
\hline \multicolumn{4}{|c|}{ Correlations $^{\mathrm{b}}$} \\
\hline & & Training (X2) & Employee Performance $(\mathrm{Y})$ \\
\hline \multirow[t]{2}{*}{ Training (X2) } & $\begin{array}{l}\text { Pearson } \\
\text { Correlation }\end{array}$ & 1 & $.599^{* *}$ \\
\hline & Sig. (2-tailed) & & .000 \\
\hline \multirow{3}{*}{$\begin{array}{l}\text { Employee } \\
\text { Performance } \\
\text { (Y) }\end{array}$} & Pearson & $.5999^{* *}$ & 1 \\
\hline & Correlation & & \\
\hline & Sig. (2-tailed) & .000 & \\
\hline $\begin{array}{l}{ }^{\star *} \text {. Correlation } \\
\text { b. Listwise } \mathrm{N}=\end{array}$ & gnificant at the & vel (2-tailed). & \\
\hline
\end{tabular}

Source: processed data (2020) 
Based on the test results obtained a correlation value of 0.599 means that training has a moderate relationship to employee performance.

Table 5. Simultaneous Correlation Coefficient Testing Results and Training Against Employee Performance

\begin{tabular}{|c|c|c|c|c|c|}
\hline \multicolumn{6}{|c|}{ Model Summary } \\
\hline Model & $\mathrm{R}$ & R Square & $\begin{array}{l}\text { Adjusted } \\
\text { Square }\end{array}$ & $\mathrm{R}$ & $\begin{array}{l}\text { Std. Error of } \\
\text { the Estimate }\end{array}$ \\
\hline $\begin{array}{l}1 \\
\text { a. Pred }\end{array}$ & $\begin{array}{l}.735^{\mathrm{a}} \\
\text { ctors: (Con }\end{array}$ & $\begin{array}{l}.540 \\
\text { raining (X2), }\end{array}$ & $\begin{array}{l}.526 \\
\text { cipline (X1) }\end{array}$ & & 2.552 \\
\hline
\end{tabular}

Based on the test results obtained a correlation value of 0.735 means that discipline and training simultaneously have a strong relationship to employee performance.

\section{Analysis of the Coefficient of Determination}

Analysis of the coefficient of determination is intended to determine the percentage of influence of the independent variable on the dependent variable either partially or simultaneously. The test results are as follows:

Table 6. Results of Discipline Determination Coefficient Tests on Employee Performance

\begin{tabular}{lllll}
\hline Model & $\mathrm{R}$ & \multicolumn{2}{c}{ Model Summary } \\
$\mathrm{R}$ Square & $\begin{array}{l}\text { Adjusted } \\
\text { Square }\end{array}$ & $\mathrm{R}$ & $\begin{array}{l}\text { Std. Error of the } \\
\text { Estimate }\end{array}$ \\
\hline 1 & $.680^{\mathrm{a}}$ & .463 & .454 & 2.738 \\
a. Predictors: (Constant), Discipline (X1) & & \\
\hline
\end{tabular}

Source: processed data (2020)

Based on the test results obtained a determination value of 0.463 means that discipline has an influence contribution of $46.3 \%$ on employee performance.

Table 7. Results of Training Determination Coefficient Tests on Employee Performance

\begin{tabular}{|c|c|c|c|c|}
\hline \multicolumn{5}{|l|}{ Model Summary } \\
\hline Model R & R Square & $\begin{array}{l}\text { Adjusted } \\
\text { Square }\end{array}$ & $\mathrm{R}$ & $\begin{array}{l}\text { Std. Error of } \\
\text { the Estimate }\end{array}$ \\
\hline $\begin{array}{lc}1 & .599^{\mathrm{a}} \\
\text { a. Predictors: (Con }\end{array}$ & $\begin{array}{l}.359 \\
\text { aining (X2) }\end{array}$ & .349 & & 2.990 \\
\hline
\end{tabular}

Based on the test results obtained a determination value of 0.359 means that training has an influence contribution of $35.9 \%$ on employee performance. 
Table 8. Results of Discipline Determination Coefficient Testing and Training on Employee Performance

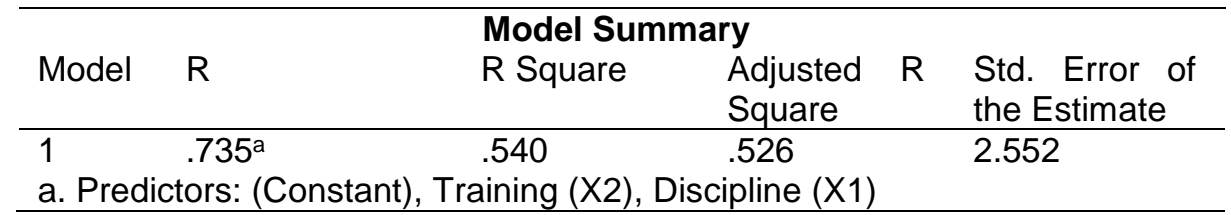

Source: processed data (2020)

Based on the test results obtained a determination value of 0.540 means that discipline and training simultaneously have an influence contribution of $54.0 \%$ on employee performance, while the remaining $46.0 \%$ is influenced by other factors.

\section{Hypothesis testing}

Hypothesis testing with a t-test is used to find out which partial hypotheses are accepted.

First Hypothesis: There is a significant influence between discipline on employee performance.

Table 9. Results of Disciplinary Hypothesis Tests on Employee Performance

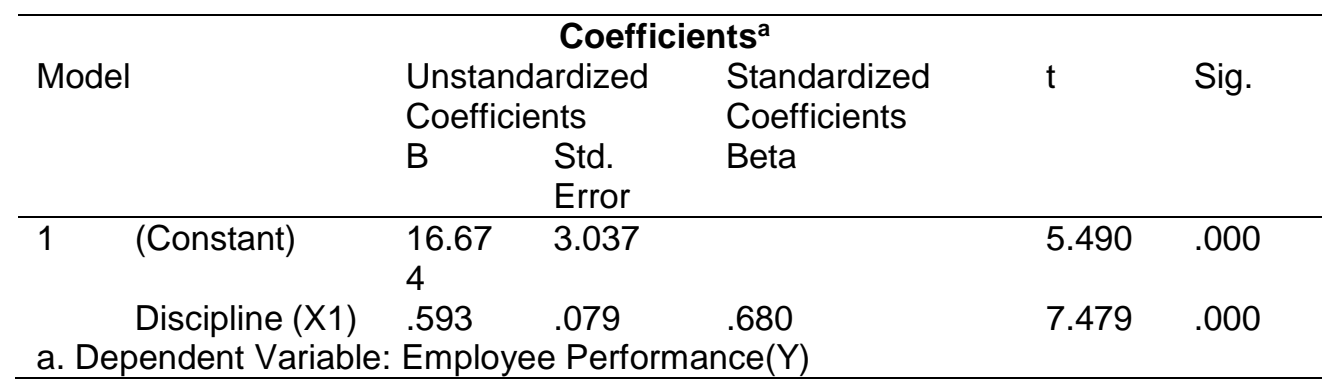

Source: processed data (2020)

Based on the test results in the above table, the value of $t$ count $>t$ table or $(7.479>1.997)$ is obtained, thus the first hypothesis proposed that there is a significant influence between discipline on employee performance is accepted.

Table 10. Results of Training Hypothesis Tests on Employee Performance

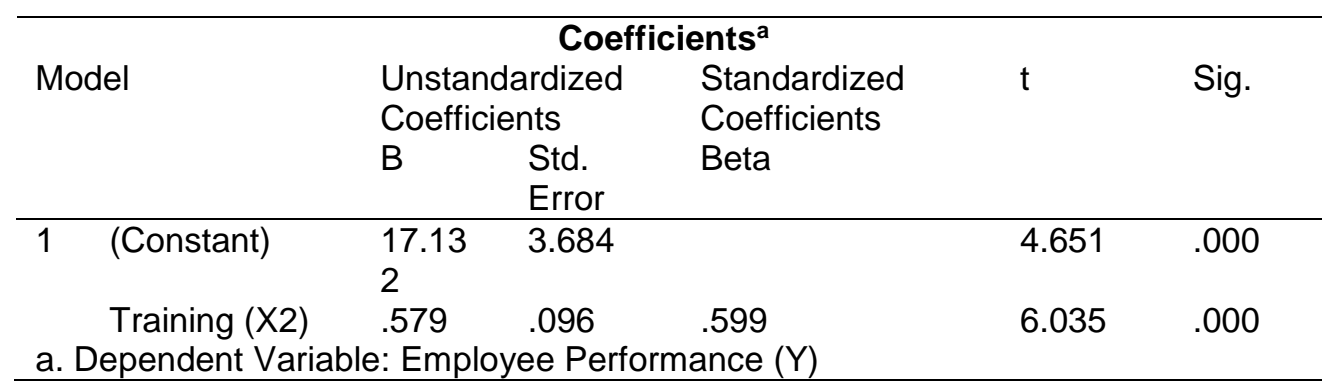

Source: processed data (2020)

Based on the test results in the above table, the value of $t$ count $>t$ table or $(6.035>1.997)$ is obtained, thus the second hypothesis proposed that there is a significant influence between training on employee performance is accepted.

Hypothesis testing with the $F$ test is used to find out which simultaneous hypotheses are accepted. 
The third hypothesis There is a significant influence between discipline and training on employee performance.

Table 11. Results of the Disciplinary Hypothesis Test and Training on Employee Performance

\begin{tabular}{|c|c|c|c|c|c|c|c|}
\hline \multicolumn{2}{|c|}{$\begin{array}{l}\text { ANOVA }^{\mathbf{a}} \\
\text { Model }\end{array}$} & \multirow{2}{*}{$\begin{array}{l}\text { Sum } \\
\text { Squares } \\
489.968\end{array}$} & & \multirow{2}{*}{$\frac{d f}{2}$} & \multirow{2}{*}{$\begin{array}{l}\text { Mean } \\
\text { Square } \\
244.984\end{array}$} & \multirow{2}{*}{$\begin{array}{l}F \\
37.6 \\
25\end{array}$} & \multirow{2}{*}{$\begin{array}{l}\text { Sig. } \\
.000 \\
\mathrm{~b}\end{array}$} \\
\hline 1 & Regression & & & & & & \\
\hline & $\begin{array}{l}\text { Residual } \\
\text { Total }\end{array}$ & $\begin{array}{l}416.718 \\
906.687\end{array}$ & & $\begin{array}{l}64 \\
66\end{array}$ & 6.511 & & \\
\hline \multicolumn{8}{|c|}{$\begin{array}{l}\text { a. Dependent Variable: Employee Performance(Y) } \\
\text { b. Predictors: (Constant), Training (X2), Discipline (Y }\end{array}$} \\
\hline
\end{tabular}

Based on the test results in the table above, the calculated $\mathrm{F}$ value $>\mathrm{F}$ table or (37.625> 2.750), thus the third hypothesis proposed that there is a significant influence between discipline and training on employee performance is accepted.

\section{Effect of Discipline on Employee Performance}

Discipline has a significant effect on employee performance with a correlation of 0.680 or has a strong relationship with an influential contribution of $46.3 \%$. Hypothesis testing obtained $\mathrm{t}$ value $>\mathrm{t}$ table or (7.479> 1.997). Thus the first hypothesis proposed that there is a significant effect between discipline on employee performance is accepted.

\section{The Effect of Training on Employee Performance}

Training has a significant effect on employee performance with a correlation of 0.599 or has a strong relationship with a contribution of $35.9 \%$. Hypothesis testing obtained $\mathrm{t}$ value $\mathrm{t}$ table or $(6.035>1.997)$. Thus the second hypothesis proposed that there is a significant effect between training on employee performance is accepted. The effect of

\section{Discipline and Training on Employee Performance}

Discipline and training have a significant effect on employee performance by obtaining a regression equation $\mathrm{Y}=10.345+0.439 \mathrm{X} 1+$ $0.319 X 2$, a correlation value of 0.735 or has a strong relationship with the contribution of influence of $54.0 \%$ while the remaining $46.0 \%$ is influenced by other factors. Hypothesis testing obtained $F$ value $>F$ table or (37.625> 2.750). Thus the third hypothesis proposed that there is a significant effect between discipline and training on employee performance is accepted.

\section{CONCLUSION}

Discipline has a significant effect on employee performance. Hypothesis testing obtained $t>t$ table. Training has a significant effect on employee performance. Hypothesis testing obtained $t>t$ table. Discipline and training have a significant effect on employee performance calculated $F$ value $>\mathrm{F}$ table

\section{REFERENCES \\ Hasibuan, Malayu S. P. (2016). Manajemen Sumber Daya Manusia. Edisi Revisi. Jakarta: Penerbit PT Bumi Aksara \\ Mangkunegara, A. A. Anwar Prabu. (2016). Evaluasi Kinerja SDM. Cetakan ke tujuh, PT Refika}


Almana : Jurnal Manajemen dan Bisnis Vol. 4 No. 2/ Agustus 2020

ISSN 2579-4892 print/ ISSN 2655-8327 online

Aditama: Bandung.

Rivai, Veithzal. (2014). Manajemen

Sumber Daya Manusia untuk

Perusahaan, Edisi ke 6. Depok:

PT. Raja Grafindo Persada.

Sutrisno, Edi. (2016). Manajemen

Sumber Daya Manusia. Jakarta:

Prenadamedia Group. 